УДК 003.314

\title{
ПЕТРОГЛИФЫ ГОРЫ АЛА-ТЕЙ \\ (НОВЫЕ ОТКРЫТИЯ НАСКАЛЬНОГО ИСКУССТВА \\ В ВЕРХОВЬЯХ ЕНИСЕЯ)
}

\author{
(C) 2021 г. И.А. Бондарь, Е.Н. Ленькова
}

Статья посвящена введению в научный оборот новых петроглифов Улуг-Хемской котловины, реки Енисей в Республике Тува. Главный объект исследования - новый памятник наскального искусства - святилище священной горы Ала-Тей. Новый памятник расположен на отдельно стоящей сопке, называемой - «гора Ала-Тей», и локализуется между хребтом Западный Саян и Танну-Ола в УлугХемской котловине Верхнего Енисея. Наскальные изображения горы Ала-Тей находят прямые аналоги в наскальном искусстве Тувы и других регионов Центральной Азии и Южной Сибири. В то же время, изображения являются уникальными, а некоторые из них не обнаруживают прямых аналогий среди петроглифов Улуг-Хемской котловины и Саянского каньона реки Енисей. В процессе исследования были выявлены: сюжет «священного брака» двух антропоморфных фигур, изображения оленей, быков, изображения рогов, астральных и космогонических символов и тамгообразные знаки. Обнаруживается большое количество сцен взаимодействий животных бронзового века, скифского и древнетюркского времени. Был произведён сравнительный анализ с известными петроглифами Тувы и сопредельных регионов, таких как: Красноярский край, Хакассия, Алтай, Байкальский регион и Монголия. Научная работа авторов призвана пролить свет на историю священной горы Ала-Тей и её сакральное наскальное искусство.

Ключевые слова: археология, Центральная Азия, Южная Сибирь, Тува, Енисей, Западные Саяны, Ала-Тей, бронзовый век, скифское время, гунно-сарматское время, древнетюркское время, тагарская культура, петроглифы, скифо-сибирский звериный стиль, монголо-забайкальский стиль, святилище, первобытная магия, астральные символы.

\section{PETROGLYPHS OF THE ALA-TEI MOUNTAIN (NEW DISCOVERIES OF ROCK ART IN THE UPPER REACHES OF THE YENISEY RIVER)}

\section{I.A. Bondar, E.N. Lenkova}

The article introduces into scientific discourse the new petroglyphs of the Ulug-Khem Depression in the Republic of Tuva. The main focus of research is a new monument of rock art - the sanctuary of the Ala-Tei sacred mountain. Rock images from Ala-Tei have many direct analogies in the rock art of Tuva and other regions of Central Asia, and Southern Siberia, at the same time being unique, and some petroglyphs has no direct parallels among the petroglyphs of the Ulug-Khem Depression, or the Sayan Gorge of Yenisei. The following items were found during the exploration: two humanoid figures with plot of the «Sacred Marriage», images of stags and oxen, images of horns, astral and cosmogonic symbols and tamgas. There are many images of the beasts of the Bronze Age, Scythian and Ancient Turkic periods. The purpose of the author's scientific work is to shed light on the history of the Ala-Tei sacred mountain, and its sacral rock art.

Keywords: archaeology, Central Asia, Southern Siberia, Tuva, Yenisei, Western Sayans, Ala-Tei, Bronze Age, Scythian period, Hunno-Sarmatian time, Ancient Turkic period, Tagar culture, petroglyphs, Scythian-Siberian animal style, Mongol-Transbaikal style, sanctuary, ancient magic; astral symbols.

В мае-июне 2019 года И.А. Бондарем было открыто и исследовано множество ранее неизвестных групп петроглифов Улуг-Хемской котловины, Верхнего Енисея, на территории Чаа-Хольского и Улуг-Хемского кожуунов Республики Тыва. Новые обнаружения были произведены на нескольких группах останцев мелкосопочного рельефа северных отрогов хребта Танну-Ола, междуречья Чаа-Холь и Шагонар, вблизи зоны затопления СаяноШушинского водохранилища (рис. 12). Были открыты несколько сотен ранее неизвестных рисунков на всей группе мелкосопочников и останцев между населёнными пунктами Чаа-Холь и Шагонар. Среди находок - изображения жилищ и загонов, личины, антропоморфные фигуры, сцены охоты, священные браки, солярные знаки, зооантропоморфные 


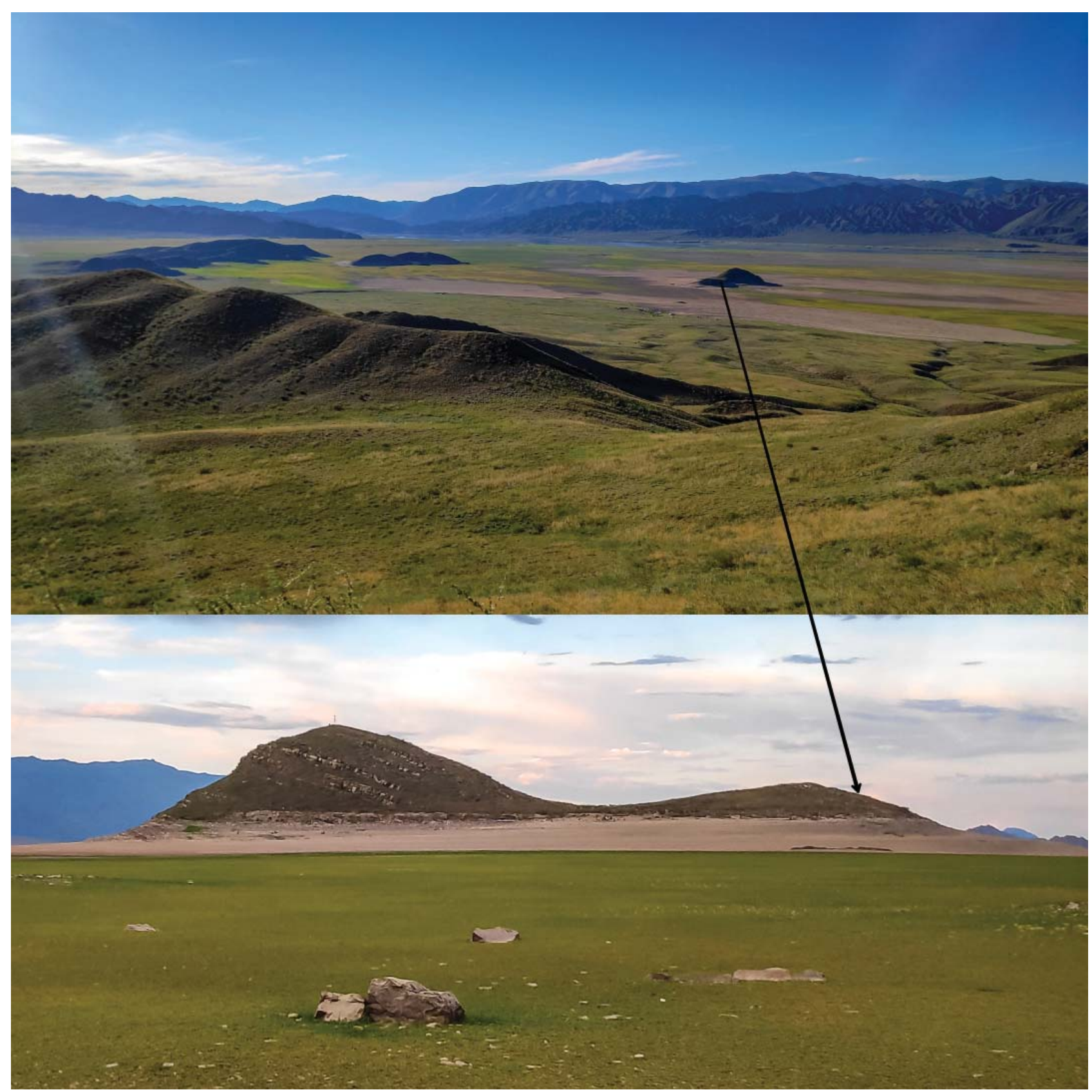

Рис. 1. Общий вид мелкосопочного останца священной горы Ала-Тей и расположение святилища на вершине южного отрога

Fig. 1. The general view of sacred mountain Ala-Tei and location of sanctuary on the top of southern part of Ala-Tei mountain.

существа, многочисленные сцены схваток и взаимодействий животных, тамгообразные знаки. Одна из таких новых зон находок - это «гора» Ала-Тей (рис. 1), петроглифы которой до июня 2019 года были неизвестны. Гора Ала-Тей - мелкая сопка, представляющая собой отдельно стоящий денудационный останец низменной долины Верхнего Енисея (рис. 10, 11, 12). Ала-Тей сложен пластами песчаников, в трещинах и полостях которых встречаются кристаллические щётки кварца с включениями эритрина и ряд других незначительных минеральных выделений цеоли- тов, карбонатов и рудных минералов. Мелкую сопку Ала-Тей продолжает невысокий, но вытянутый в южном направлении скалистый отрог, связанный с главным конусовидным возвышением единой геоморфологией. Южная оконечность отрога имеет небольшой подъём относительно некрупной седловины, соединяющей южную оконечность отрога с основным конусом Ала-Тея (рис. 1). Именно на небольшом возвышении южной оконечности отрога локализуется основная группа петроглифов, представленная плоскостью, на которой выбито множество наскальных 
изображений (рис. 2). Петроглифы объединены единым сюжетным замыслом. Вблизи от главной плоскости располагаются несколько отдельно стоящих петроглифов и тамг. На других участках Ала-Тея встречаются единичные наскальные изображения животных, солярные знаки, тамги.

Ала-тей, скалистый останец, предстающий как отдельно стоящее конусовидное возвышение на открытой барханной равнине (рис. 1), являлся для многих народов в разные эпохи священным местом и, по всей видимости, объектом поклонения. Об этом свидетельствуют не только сакральные петроглифы с явным магическим назначением, но и множество захоронений средневекового, гунно-сарматского ${ }^{1}$ и раннескифского времени (Бусова, Килуновская, Леус, Орфинская, 2019 , с. 155-158, рис. 1, 2), расположенных вокруг сопки (Kilunovskaya, Leus, 2018, p. 2-3, fig. 3, 4; p. 5, fig 9; Мурзина, 2020, с. 273-275)2. Множество предметов принадлежности различным материальным культурам, от палеолита до позднего Средневековья, обнаруживаются на склонах и у подножья горы, по-видимому, оставленных ей в качестве преподношения.

Главная плоскость петроглифов горы Ала-Тей. На вершине небольшого возвышения южной оконечности отрога располагается плоскость, на которой нанесено множество петроглифов, по всей видимости, объединённых общим сюжетным замыслом художника (рис. 2, 3). Плоскость располагается в верхней части южной окраины пласта девонского песчаника, залегающего под наклоном порядка $45^{\circ}$, и локализована в пределах 1 $\mathrm{M}^{2}$. Рисунки, представленные на плоскости, имеют разную степень сохранности и выразительности. Поверхность рабочей зоны каменной плиты насыщена петроглифами, а центральная и правая части плоскости выражают отчётливые проявления палимпсестов. Отмечаются следы деформации и механического разрушения правого края поверхности плоскости и крупного фрагмента на нижнем участке плоскости (рис. 2). Правый край несёт следы более позднего и намеренного уничтожения небольшого участка петроглифов, что выражается и в характере скола, и в обнажившемся светло-зелёном песчанике. Крупный скол нижнего участка, имеющий харак- тер выемки, покрылся сравнительно тонким слоем минерализованной корки «пустынного загара», что говорит о более раннем воздействии на каменное полотно наскального изображения. На поверхности правого края плоскости отчётливо фиксируется повреждение петроглифов.

Изображения петроглифов выполнены в технике мелкой точечной выбивки, с элементами протирки изображения. Рисунки несут неглубокий, поверхностный характер. Густота соседствующих петроглифов варьируется от частой очерёдности до густого скопления на центральном участке. Размер петроглифов колеблется от маленького до среднего, форма петроглифов округлая, местами удлинённая. Сложность изображения петроглифов разнится от примитивных фигурок до усложнённых и витиеватых с дендроидными замысловатыми рогами животных.

К сожалению, из-за высокой плотности палимпсеста и плохой сохранности ряда рисунков уверенная идентификация и интерпретация некоторых петроглифов весьма затруднительна и не может быть однозначной, в то время как другие рисунки могут быть интерпретированы с высокой долей вероятности или же их идентификация и интерпретация не вызывает никакого сомнения.

Левый край плоскости представлен, по-видимому, одним из самых крупных рисунков наскальной композиции. Петроглиф изображает оленя, развёрнутого к краю плиты, с мощными и разветвлёнными рогами (рис. 3). Симметрия рогов животного нарушена, одна половина гипертрофированно увеличена, возможно, являет собой более позднюю дорисовку. Изображение несёт следы как точечной выбивки, так и протирки. Петроглиф оленя левого края плоскости снизу окружён небольшими фигурками четырёх козлов, самая крупная из которых выделена особо чётко и является самым крайним петроглифом левого края плоскости. Остальные три фигурки просматриваются в разной степени хуже, скорее всего, по причине новых минеральных выделений «пустынного загара» на их изображении. Разница в чёткости изображений в данном случае может быть объяснена тем, что в более позднее время поклонявшиеся камню избирательно усиливали изображения некоторых петроглифов, выделяя их снова по 


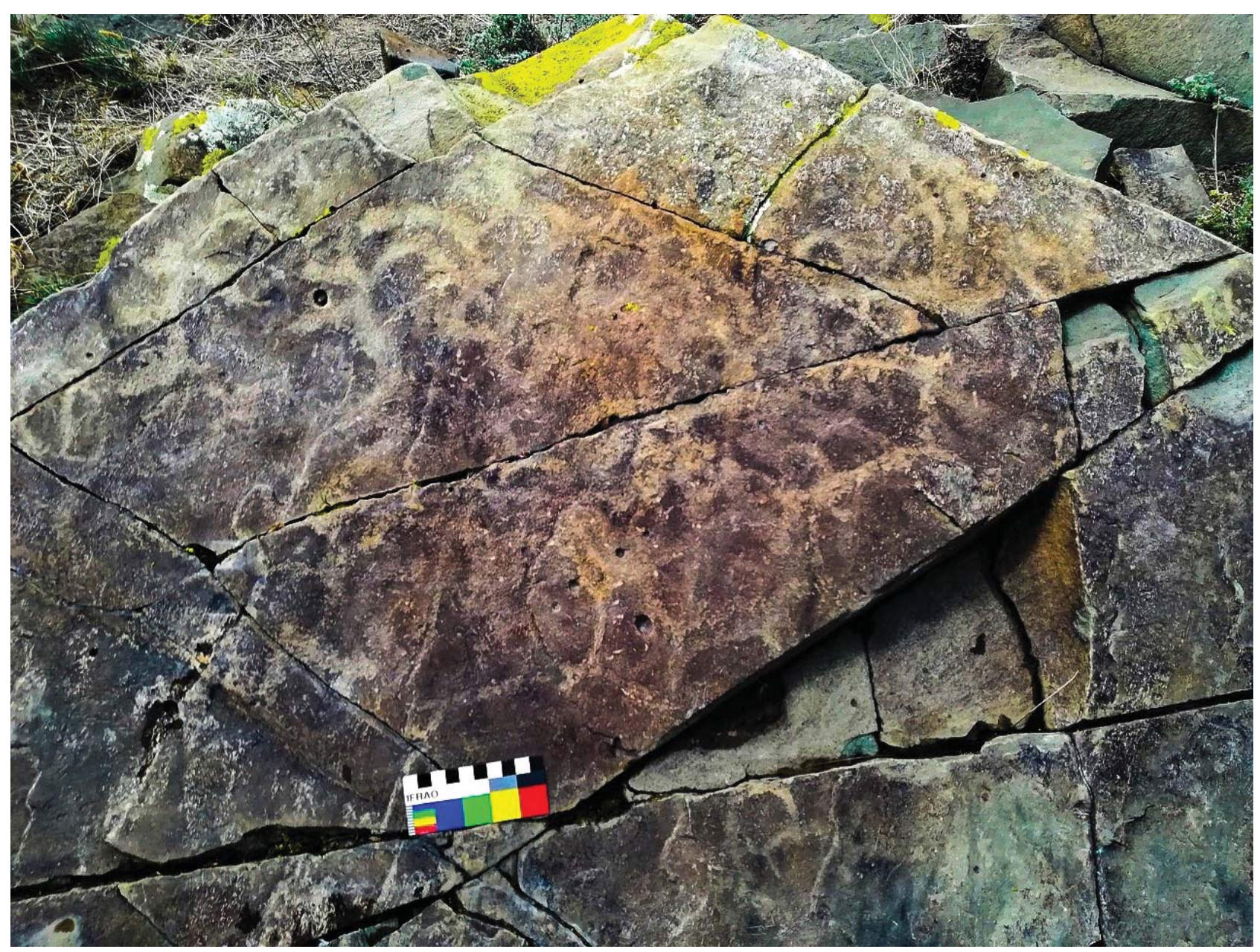

Рис. 2. Общий вид главной плоскости петроглифов Ала-Тея

Fig. 2. The general view of main surface of the rock with petroglyphs of Ala-Tei.

старому изображению. Разумеется, «реставраторами» могли браться в расчёт наиболее «важные» в сакральном отношении рисунки, как и те, которые на момент воссоздания были более различимы и понятны.

За петроглифом большого оленя левого края с аналогичным характером расположения находится немного меньший по размеру рисунок, изображающий вытянутое и изогнутое к центру композиции животное, напоминающее козла. Рядом с этим петроглифом находится фигура, изогнутая в том же направлении, крючковидный рог которой пересекается с рогом животного, напоминающего козла (рис. 3). Фигура с крючковидным рогом не поддаётся однозначной интерпретации, однако безо всякого сомнения перед нами сцена противостояния, борьбы двух зооморфных образов. Возможно, художник попытался передать борьбу козла с рогатым змеем или же двух козлов, однозначно сказать уже не представляется возможным. Правее ещё одна фигура как бы топчет своими передни- ми ногами фигуру с крючковидным рогом и напоминает образ оленя. Располагается фигура на самом верхнем участке плоскости. Под задними ногами этой фигуры находится неотчётливое изображение перевёрнутого горного козла, также противостоящего фигуре с крючковидным рогом. Их рога также соприкасаются, не смыкаясь. Возле перевёрнутого козла в центральной зоне явно обнаруживаются четыре фигуры небольших оленей, схожих по размеру. Изображения животных местами накладываются друг на друга, животные показаны в движении и в противоборстве, а рога двух оленей, скачущих в разные стороны, показаны сцепленными между собой.

В нижней части плоскости едва просматривается изображение крупного рогатого животного, расположенного горизонтально. Петроглиф покрыт тонкой плёнкой пустынной минерализации. Ещё ниже процарапаны две примитивные фигуры животных, показанных в противоборстве. Изображения исполнены местами простой линией, местами намечен 


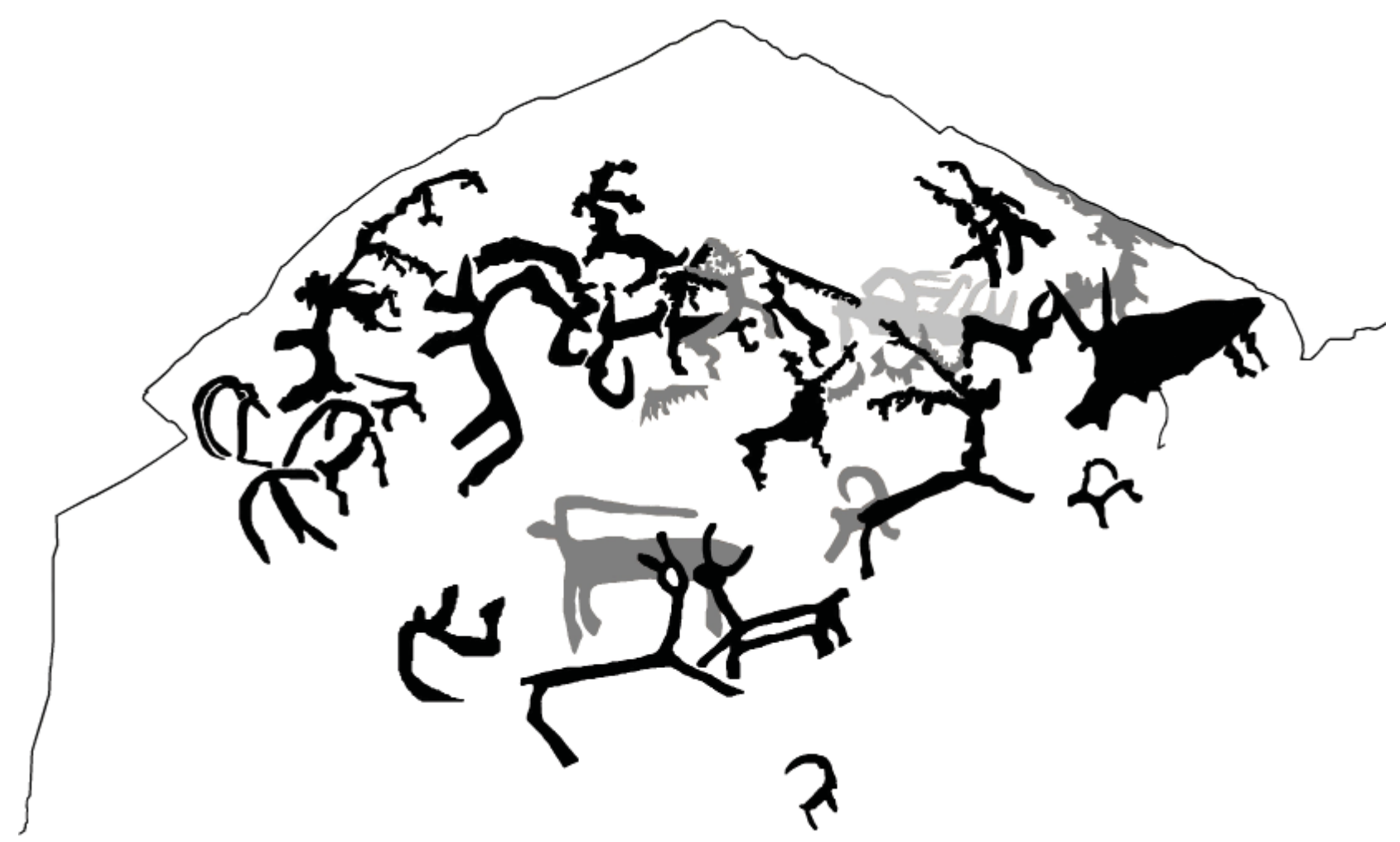

Рис. 3. Прорисовка петроглифов главной плоскости святилища «южный Ала-Тей».

Fig. 3. The outline of petroglyphs of main surface of the rock of "The southern Ala-Tei sanctuary".

контур, отмечается палимпсест с вышерасположенной фигурой рогатого животного.

Правее расположена ещё одна крупная фигура оленя, голова которого хорошо проработана и выделена. Фигура оленя располагается в правом секторе плоскости, и её рога накладываются на зону сильного палимпсеста по меньшей мере пяти петроглифов ${ }^{3}$. Один из петроглифов зоны сильного палимпсеста имеет более явные очертания и может быть выделен и идентифицирован как фигура небольшого быка, показанного в схватке с фигурой правого края плоскости (рис. 3).

Петроглиф правого края плоскости несёт следы намеренно выбитой породы (рис. 2), однако сохранились общие очертания вокруг выбоины, позволяющие «реконструировать» предполагаемый вид (рис. 3). Петроглиф изображает животное, имеющее общие черты быка и вепря, однако может являться и наложением двух животных. Схожее изображение имеется на писанице Бежиктиг - Хая Хемчикской котловины (Дэвлет, 1990, с. 86). Над рогами двух противоборствующих фигур правого края плоскости находится петроглиф, изображающий оленя.

Венчают композицию две расположенные выше антропоморфные фигуры, по-видимому, изображающие мужчину и женщину в удлинённых головных уборах (рис. 3). По всей видимости, петроглифы выражают концепцию «священного брака». Похожие головные уборы находят свои аналогии на целом ряде петроглифов региона. В частности, они представлены на петроглифах Верхнего Енисея (Семёнов, 2015, с. 149) и относятся к тагарской культуре. Аналогии обнаруживаются на рисунках Майдашинской писаницы, вблизи деревни Быстрая на Среднем Енисее (Дэвлет, Бадер, Даркевич, Леонтьев, 1979, с. 224--225; Панкова, 2005, ил. 6), на петроглифах писаницы горы Полосатая (Панкова, 2005, ил. 84). Схожие аналогии предстают на петроглифах Шалаболинской писаницы Среднего Енисея (Дэвлет Е.Г., Дэвлет М.А., 2011, с. 299, рис. $3: 15$; с. 266 , рис. $3: 28$; Зоткина, 2014, с. 92 , рис. 5:2). Встречаются они и на писанице Хызыл-Хая на берегу реки Аскиз в Хакассии (Панкова, 2005, ил. 2), и среди наскальных изображений горы Туран. (Миклашевич, 2018 , с. 34 , рис. 5 ; с. 32 , рис. $4: 5-7)$. Схожий головной убор отмечается на раннесредневековой антропоморфной железной статуэтке из Корсаковского грунтового могильника на Нижнем Амуре (Медведев, 1979, с. 252). Стоит отметить, что специфические головные 


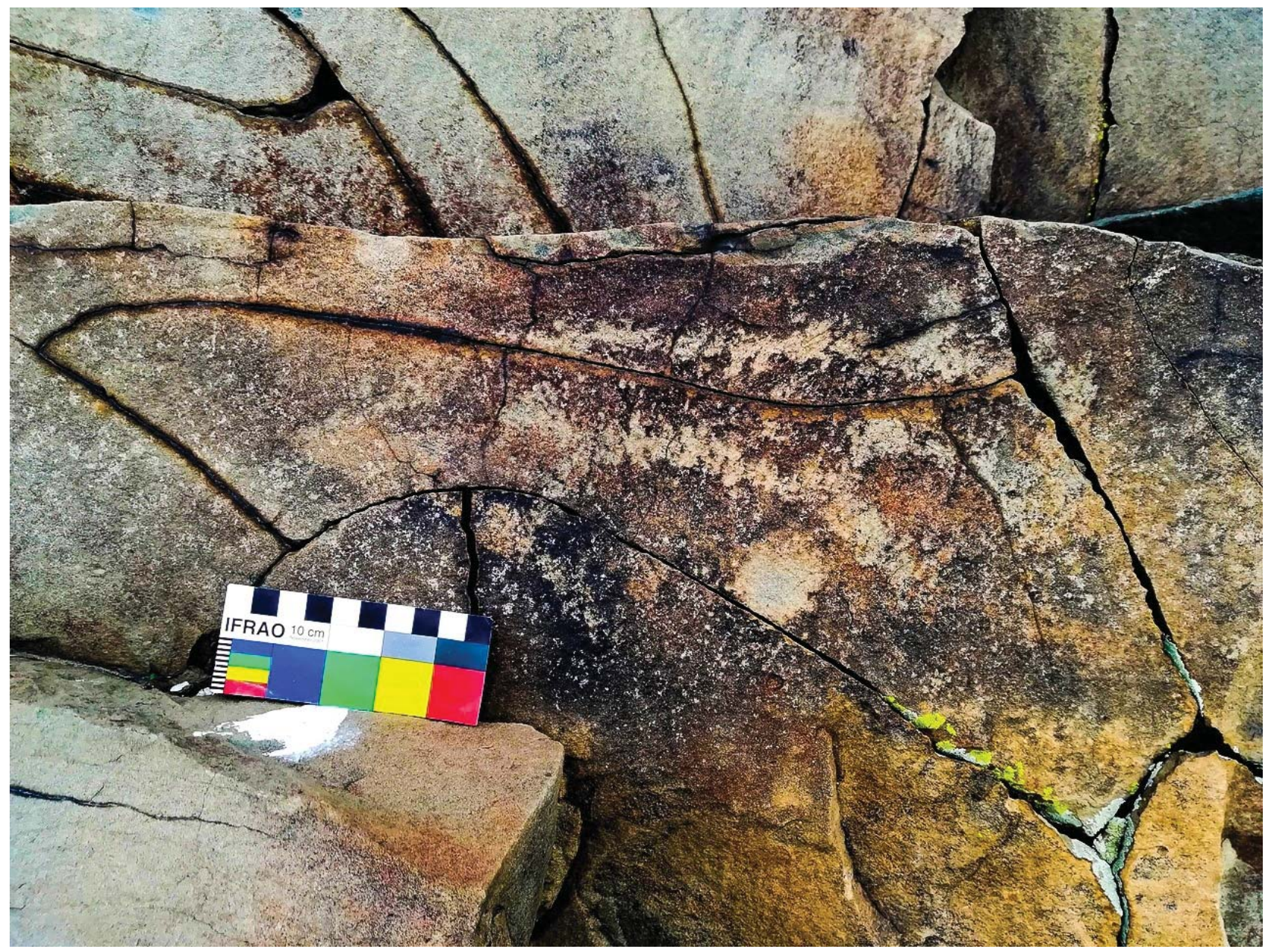

Рис. 4. Прорисовка оленя с астральным знаком. «Святилище южный Ала-Тей».

Fig. 4. The outline of the deer with astral symbol."The southern Ala-Tei sanctuary".

уборы, возможно и причёски, встречаются на антропоморфных фигурах региона не только в виде удлинённых наверший, но и в грибовидном обличии так называемых «людей-мухоморов».

Примечательным является исполнение рисунков плоскости. Животные показаны в движении, некоторые фигуры достаточно сильно выгнуты (рис. 3), что находит свои аналогии в скифском зверином стиле тагарской культуры (Семёнов, 2015, с. 146, рис. 221). Характер изображения оленей также перекликается со скифским звериным стилем (Дэвлет, 1980, с. 205-207), что также находит близкие аналогии среди тагарской традиции (Семёнов, 2015, с. 143, рис. 212; с. 144, рис. 213-214).

Некоторые петроглифы несут яркие следы обновления в более позднее время, в частности об этом красноречиво говорит самый нижний отдельно стоящий петроглиф горного козла, на котором выделены рога, в то время как остальное туловище покрыто тонким слоем пустынного загара (рис. 2). По-видимому, было выделено именно то, что более поздний художник считал самым важным - рога животного. В этом, несомненно, отражается мировоззрение древних, нашедшее своё выражение в первобытной магии, отразившейся на петроглифах Ала-Тея. Отдельно стоит отметить одиночные изображения оленьих рогов на плоскости, что может быть объяснено процессом деградации петроглифов более раннего слоя по причине новообразованного пустынного загара плоскости девонского песчаника, но с сохранением силуэта рогов животных в силу их почитания и систематического обновления поздними почитателями «каменного полотна». Изображение оленьих рогов было призвано исполнять роль магического тотема-защитника вместо самого оленя (Новгородова, 1984, с. 79). Однако в данном случае нельзя однозначно утверждать то, что рога были нанесены на плоскость в качестве самостоятельной задумки. Палимпсест и уничтожение петроглифов в ряде случаев 


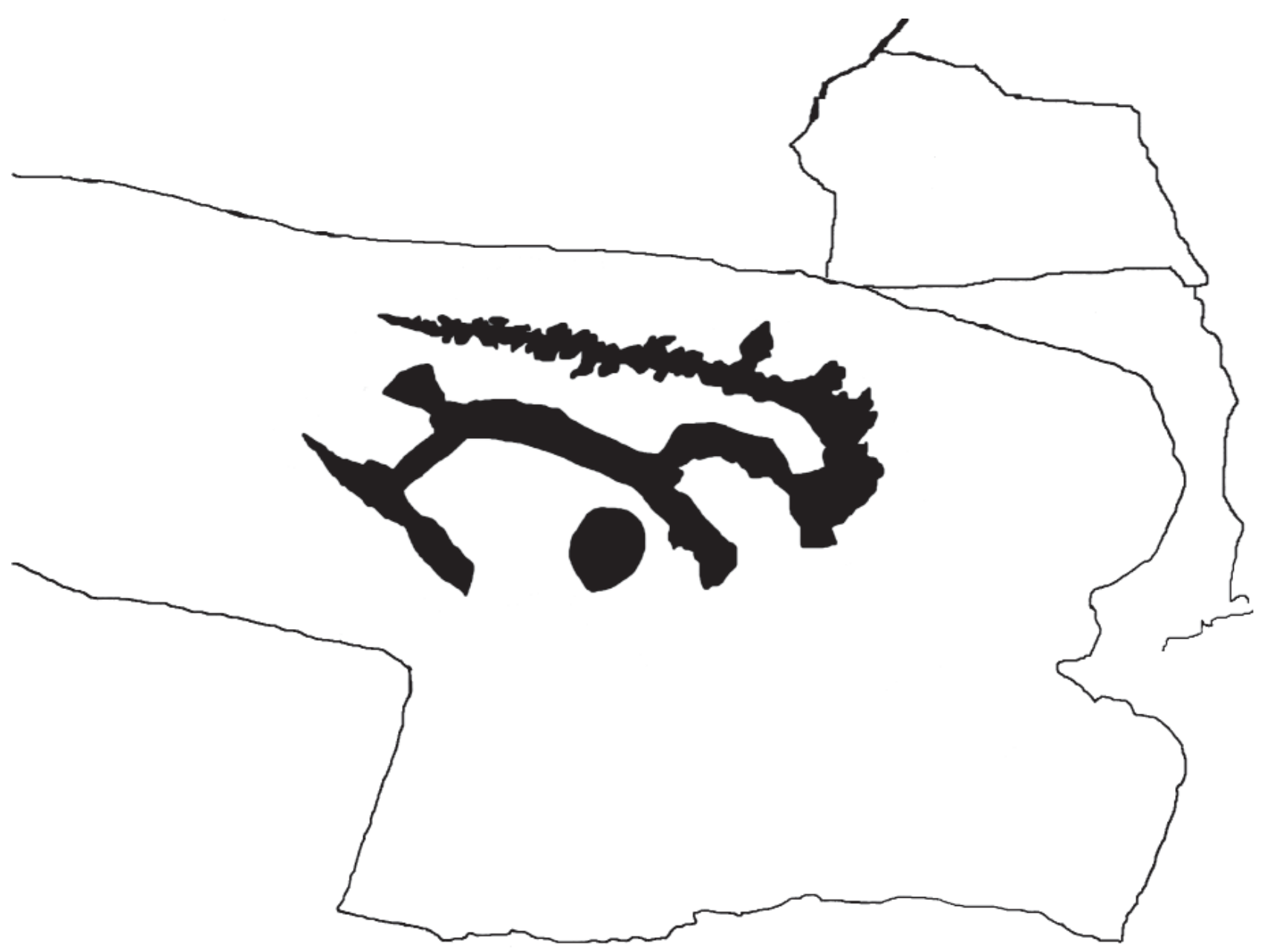

Рис.5. Плоскость изображения оленя с астральным знаком.

Fig. 5. The surface of the rock with image of the deer with astral symbol.

может являться способом «перебить» магию священных изображений.

В нескольких шагах от главной плоскости располагается ещё один выход пласта девонского песчаника, крайняя южная часть отвеса скалы имеет две условно вертикальные и перпендикулярные друг другу плоскости с наскальными рисунками. Расстояние между плоскостями порядка 1 м, а расположение одной плоскости по отношению к другой порядка $90^{\circ}$. На первой плоскости изображено крупное животное, профиль которого напоминает оленя скифской традиции. Животное изображено над солярным диском и «скачет» в южном направлении (рис. 4). Петроглиф относительно крупного размера, очень чёткий, выполнен техникой мелкой выбивки, астральный диск имеет следы дополнительной протирки (рис. 5). Региональные аналогии встречаются на северо-западе Монголии, в группах петроглифов эпохи неолита и бронзового века Цагаан-Салаа и Бага-Ойгур, в горах Алтая. Так, например, среди многочисленных петроглифов Цагаан-Салаа и Бага-Ойгур отмечается аналогичное по замыслу и концепции изображение священного быка, под которым выделяется такого же типа астральный диск (Кубарев, 2006, с. 42, рис. 3:18). В Сибири известен образ коня с расположенным астральным диском под копытами (Голан, 1993, рис. 64:1). На юго-западном угловом камне каменной оградки раннетагарского кургана в Хакасии было обнаружено выбитое изображение горного козла с лучистым солярным диском под копытами (Маннай-Оол, 1967, с. 142, рис. 1:3). Изображение фигуры оленя с солярным диском под копытами воплощено в деревянном украшении головного убора пазырыкской культуры в Уландрык IV, курган 5. Ещё одно изделие в виде бронзовой женской шпильки для волос, изображающей фигуру коня с солярным диском под копытами, происходит из соседнего кургана 2 в Уландрык IV на российском Алтае (Кубарев, 2006, с. 43, рис. 5; рис. 7). Таким образом, перед нами изображение животного, «маркированного» маги- 

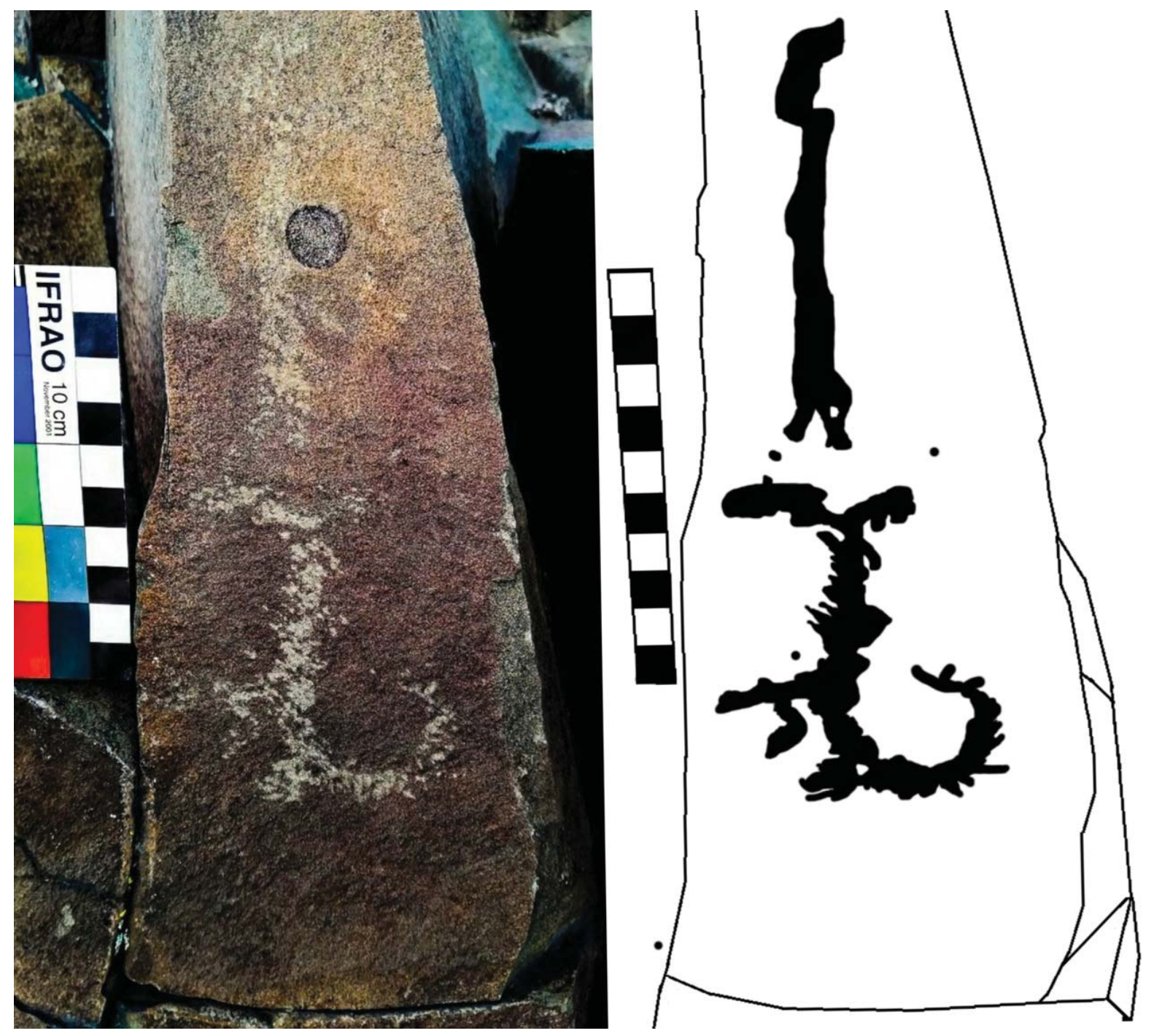

Рис. 6. Плоскость и прорисовка изображения горного козла бегущего от змея. Святилище южный Ала-Тей. Fig. 6. The plain and outline of image of the "mountain goat running away from the snake".

"The southern Ala-Tei sanctuary".

ческим астральным знаком, что делает его сакральным и поклонным в контексте представлений о первобытной магии.

Вторая плоскость изображает небольшую фигуру горного козла в движении, о чём говорит приподнятая передняя лапа животного, фигура «движется» сверху вниз (рис. 6). Сюжет изображения состоит в том, что за горным козлом пустилась в погоню довольно крупная змея с раскрытой пастью. Судя по характеру композиции, козёл бежит вниз с горы, а за ним вдогонку устремился змей. Петроглиф козла выполнен в такой же технике, как и соседствующий с ним петроглиф «астрального оленя» на соседней плоскости. Профиль мчащегося от змеи горного козла вниз по склону изображён с выделенным зрительным органом. Немного продолговатые удары мелкой точечной выбивки, нане- сённые под определённым углом, слегка имитируют туловище животного, покрытое шерстью (рис. 6). Данное изображение парнокопытного животного в сюжете со змеёй - не единственное из открытых И.А. Бондарем петроглифов горы Ала-Тей и соседних мелкосопочных останцев. Ближайшая по соседству аналогия - это горный козёл, изображённый в схватке с огромным рогатым змеем, на одной из террас горы Ала-Тей. Изображение выполнено в технике глубокой точечной выбивки, козёл представлен с четырьмя лапами и двумя рогами (рис. 7). Ещё одна аналогия находится в непосредственной близости от горы Ала-Тей, на плите южного склона соседнего мелкосопочного останца - горы Ытыг-АтыгТей, и открыта Е.Н. Леньковой. Здесь, в яростной схватке со змеем, показан олень скифской изобразительной традиции ${ }^{4}$. Имеются 


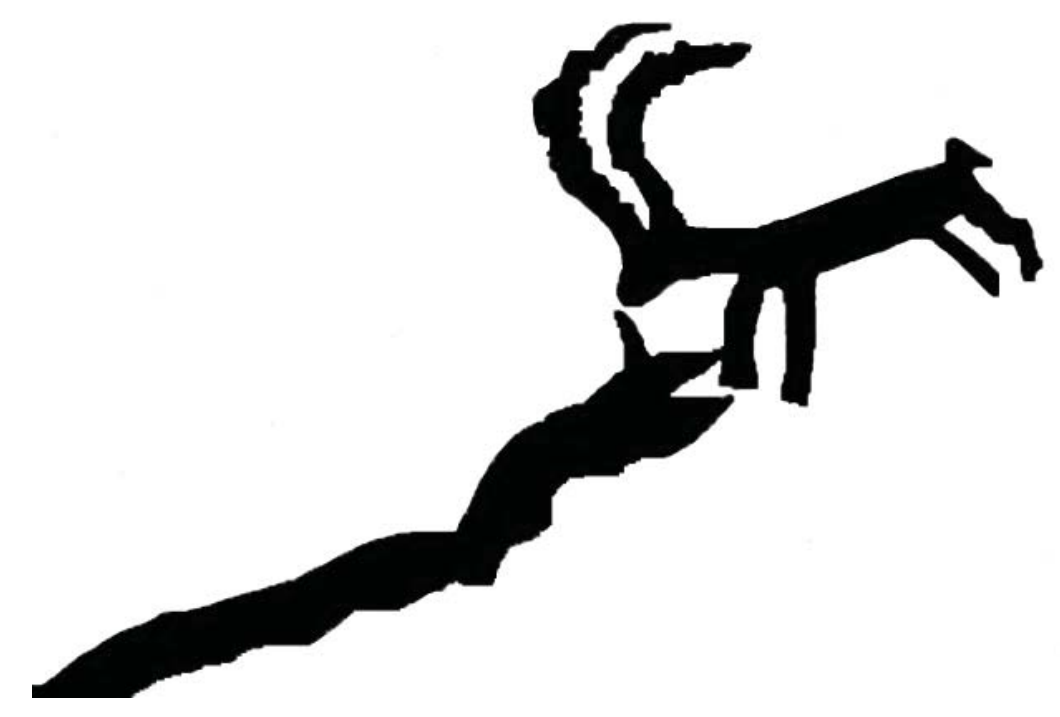

Рис.7. Прорисовка изображения схватки горного козла и рогатого змея на скалах Ала-Тея. Fig. 7. The outline of image of "fighting of mountain goat with Horned Serpent along Ala-Tei cliffs".

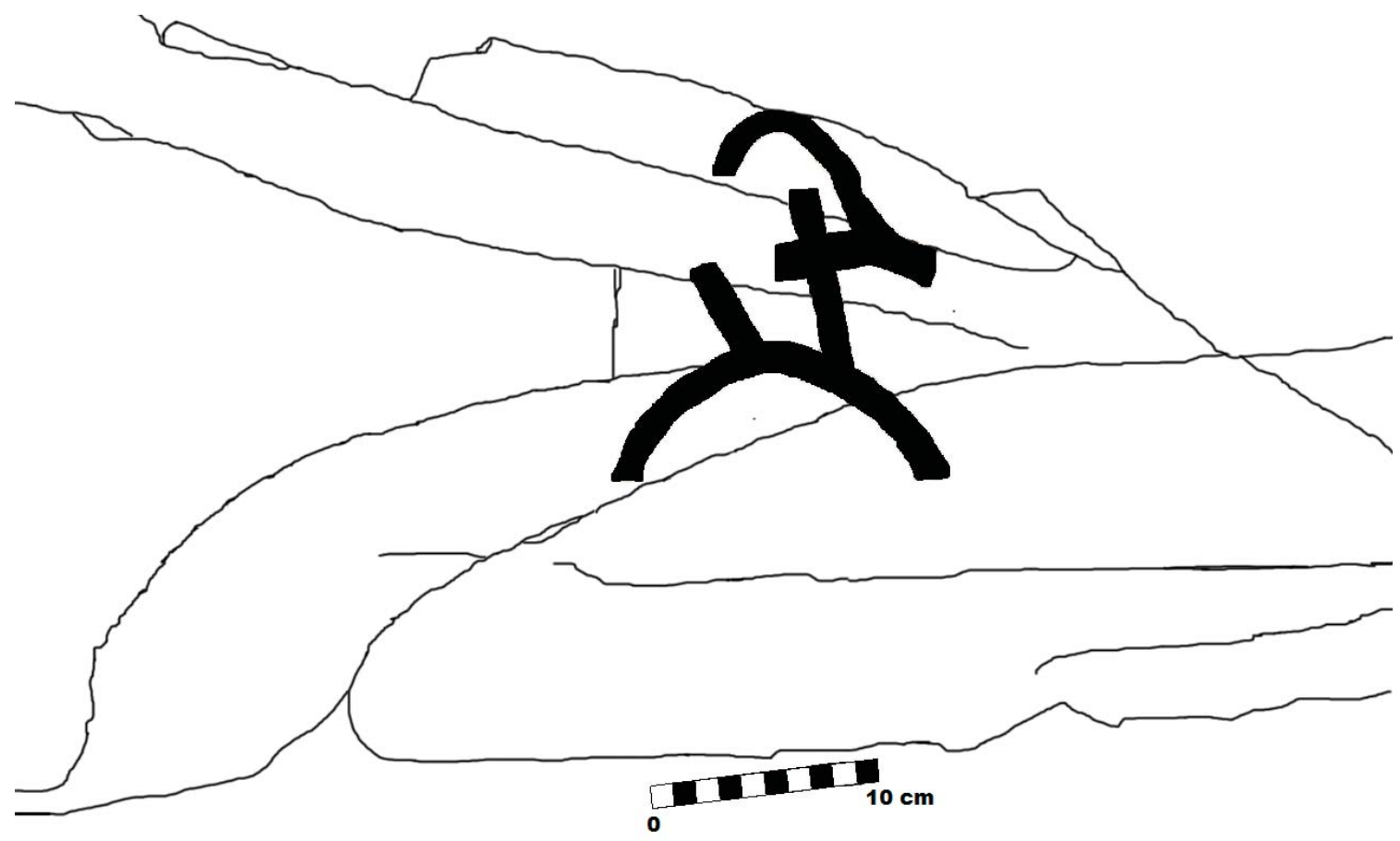

Рис. 8. Прорисовка тамгообразного знака, развившегося из сакрального образа космогонического горного козла. Fig. 8. The outline of tamga symbol, developed from sacral image of "astral mountain goat". 


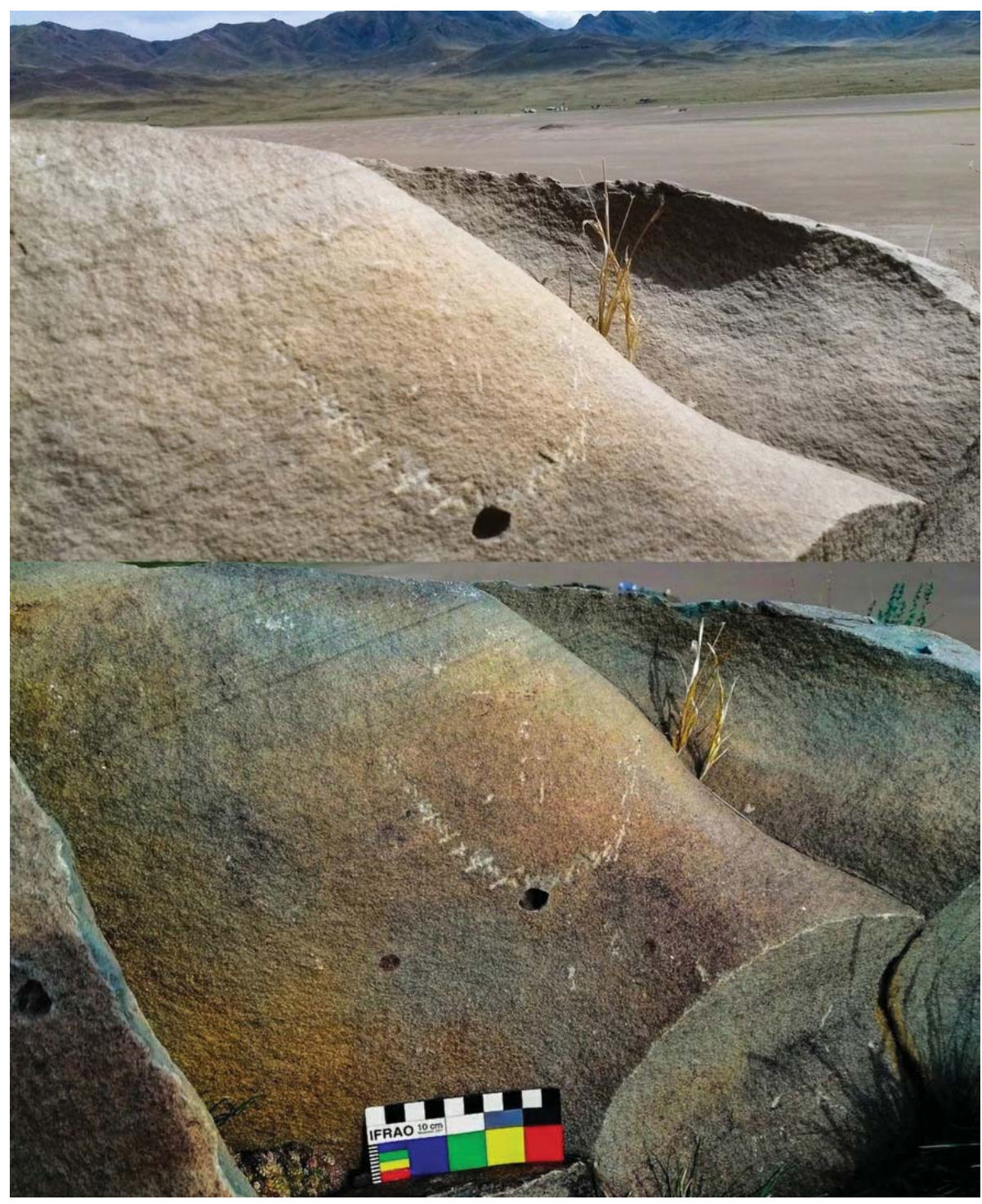

Рис. 9. Тамгообразный знак «дуга» с видом на седловину соседней горы системы Танну-Ола.

Fig. 9. The tamga symbol "arch" with view of the mountain-saddle of neighboring mountain of Tannu-Ola mountainsystem in the background.

и другие сюжеты со змеями из нового материла исследуемой зоны. Стоит отметить, что сюжет противоборства парнокопытного животного со змеем является относительно распространённым. Так, например, сюжет с участием образа млекопитающего и рептилии представлен на плоскости Овюр XII, объект 22 (Грач, 1958, табл. XLVII:2). Композиция козла, оленя со змеем довольно часто встречается в наскальной живописи Саяно-Алтайской горной страны древнетюркского времени (Самашев, Базылхан, 2010, с. 142, табл. 1:13-15). Семантика композиции взаимодействия парнокопытного со змеем может отражать воззрения, наделяющие коня, козла или оленя светлым, божественным, выступающим в образе духа природы или же олицетворяющим Солнце значением, а змея - хтонической сущностью, олицетворяющей зло и преисподнюю (Голан, 1993, с. 237).

Тамгообразные знаки горы Ала-Тей. Вблизи описанных плоскостей петроглифов вершины южного возвышения Ала-Тея находится вертикальная плоскость, на которой выгравирован тамгообразный знак, стилизованный под образ козла (рис. 8). Знак состоит из прямой полосы, пересечённой короткой поперечной линией и переходящей в нижней части в дугу, от которой с креном влево исходит ещё одна короткая полоса. От правого края короткой поперечной линии отходит небольшой дугообразный элемент, напоминающий рог козла. Отдалённая по схожести тамга встречается среди наскальной живописи пункта Овюр XII, объект 12 (Грач, 1958, табл. XLIII:2), и отличается, прежде всего, 


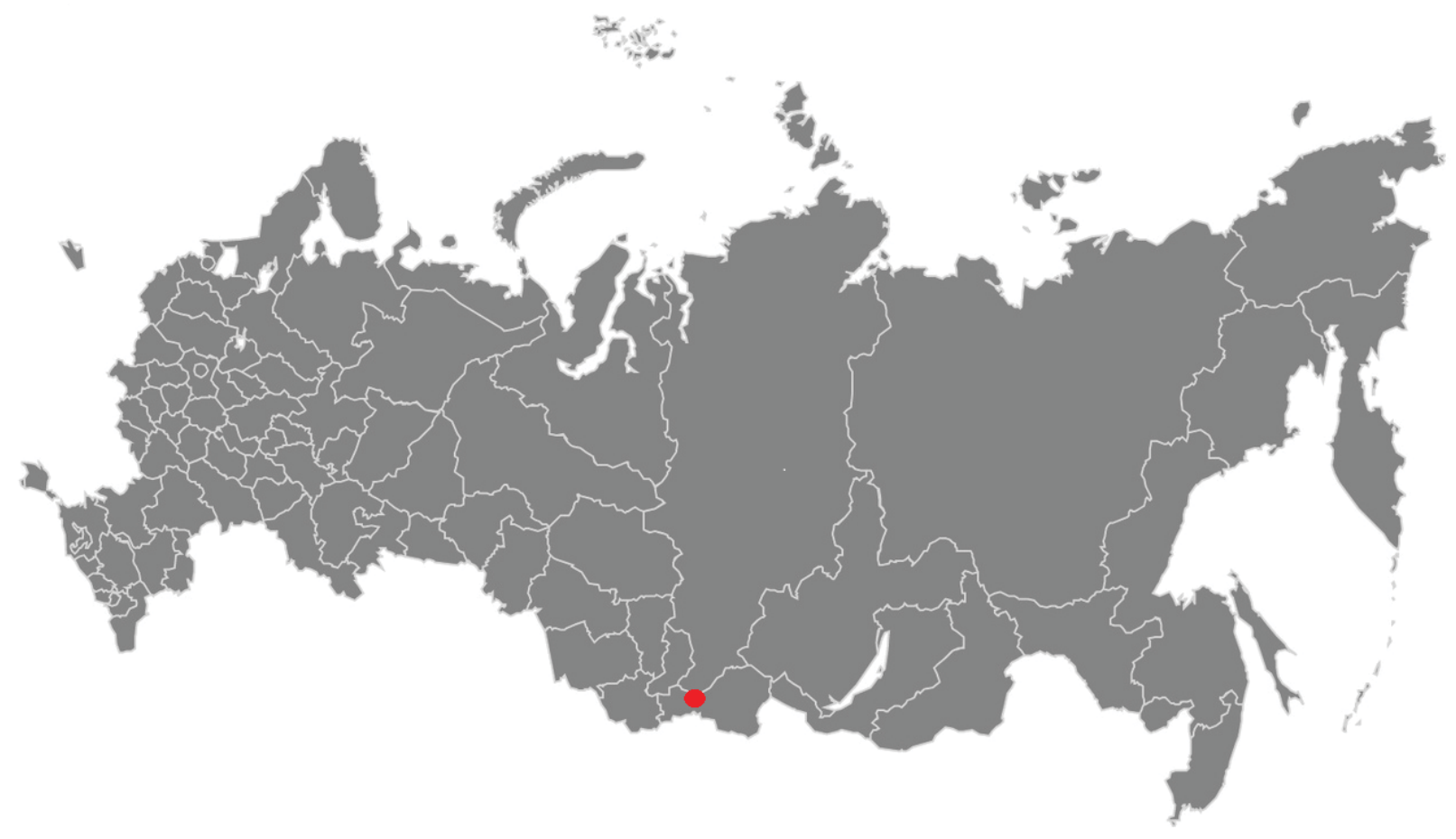

Рис. 10. Карта Российской Федерации с точкой обозначения горы Ала-Тей.

Fig. 10. The map of Russian Federation with point of location of Ala-Tei mountain.

перевёрнутым видом, отсутствием рога выше короткой пересечены и размещением отростка вовнутрь дуги, а не снаружи. Схожие по концепции тамгообразные знаки широко встречаются у енисейских кыргызов (Есин, 2017, с. 65, рис. 7; Длужневская, Савинов, 2007 , с. 155-159), на туранской писанице (Миклашевич, 2018, с. 31, рис. 3:3; с. 35, рис. 7:4), на оленных камнях Тувы (Килуновская, Семёнов, 1998, с. 146 , рис. 4:1). Известно, что в древнетюркское время в качестве родоплеменных знаков использовались тамги, стилизованные под изображение горного козла, однако дугообразная часть семантически может быть связана с полумесяцем и нести космогоническую составляющую (Самашев, Базылхан, 2010, с. 146-159). Тамгообразный знак южного возвышения Ала-Тея идентифицируется как родоплеменная древнетюркская тамга (рис. 8). Знак находит большое количество схожих по начертанию, назначению, стилистике, семантике сопоставлений, но в то же время в настоящем исследовании не удалось выявить точную аналогию тамгообразному знаку.

По соседству, на верхнем сколе вертикальной плоскости скалы, выбит дугообразный знак в виде полумесяца, лежащего на боку и ориентированного рожками вверх, в южном направлении (рис. 9). Дугообразный знак напоминает ожерелье или пектораль. Любопытно, но дугообразный знак в значительной степени повторяет контуры седловины горы хребта предгорья Танну-Ола, расположенной на одной визуальной линии с наблюдателем, смотрящим на дугообразную выбивку (рис. 9). Знак повторяет очертание дуги большого количества древнетюркских тамг (Миклашевич, 2018 , с. 35 , рис. $7: 4$ ), в то же время известны и древнетюркские тамги, изображающие только дугу (Самашев, Базылхан, 2010, с. 147-148, 8-8.2). Семантика таких изображений также связана с астральной значимостью лунарнаго знака в космологических представлениях древних.

На отвесных скалах террас Ала-Тея обнаружен также гаммированный знак, представляющий собой довольно крупную выбивку свастики, которая может являться как солярным знаком, так и родоплеменной тамгой.

В расщелине между выходами двух пластов восточного обрывистого склона в конце мая 2019 года И.А. Бондарем обнаружена тамга крупных размеров, нанесённая на вертикальную плоскость расщелины. Тамга представляет собой несколько концентрированных кругов, помещённых один в другой, между которыми лучатся соединяющие их короткие перекладины. В центре композиции имеется небольшая окружность, в которую помещён 


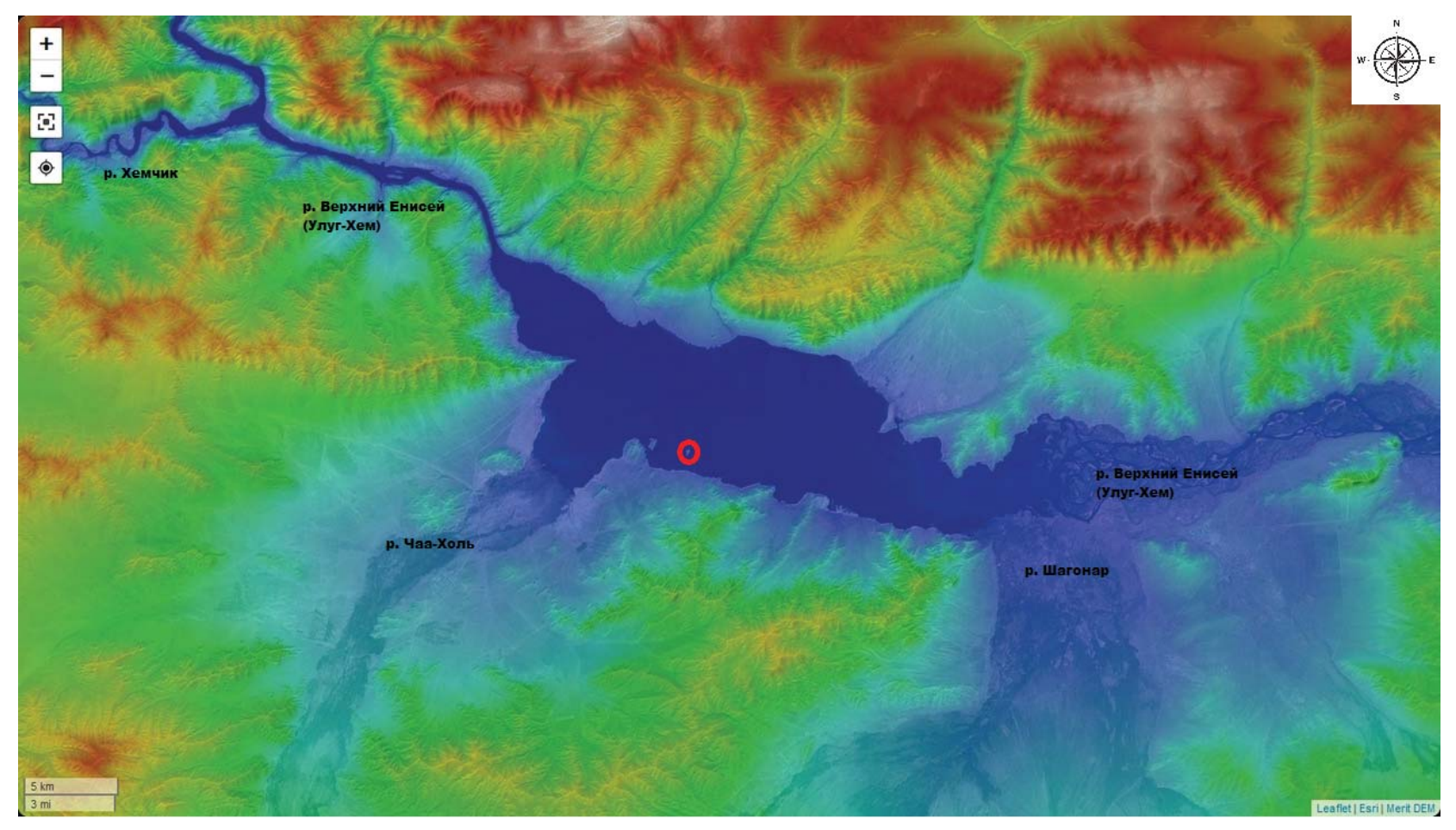

Рис. 11. Локализация горы Ала-Тей на карте Улуг-Хемской котловины.

Fig. 11. The map of Ulug-Khem Depression with localization of Ala-Tei mountain.

«S-образный» символ. «S-образный» символ встречается в качестве тамгообразного знака как в гунно-сарматское время, так и в древнетюркское время. Тамга сына Чингисхана, хана Угэдэя, также изображена в виде «S-образного» символа (Badarch, 2005, с. 45-53). Для более подробного изучения необходимо продолжить исследование и фиксацию знака на месте.

Выводы и заключение. Петроглифы вершины южного возвышения священной горы Ала-Тей представляют собой древнее святилище, что вполне обосновывается в контексте настоящего исследования и анализа собранного материала. На небольшом участке компактно расположены наскальные рисунки, содержащие: астральные знаки, сцены борьбы животных, гиперболизированные рога животных, множество отдельно расположенных рогов, тамгообразные знаки. Ряд петроглифов святилища несёт в себе явные следы как почитания и «усиления» первобытной магии, так и следы противоборства с магией сакральных знаков путём перебивки изображения и его грубого физического уничтожения избирательного характера.

Первые рисунки в святилище могли появиться ещё во времена каменного века, об этом говорит нахождение многочисленных каменных орудий труда, отщепов, скребков, ножей, стрел, нуклеусов, микролитов, изготовленных из местного жильного кварца белого и чёрного цветов и часто встречающихся от самой вершины Ала-Тея до его подножья. Помимо этого, на северном крутом склоне главного возвышения Ала-Тея расположен небольшой грот, в котором древний человек мог прятаться от палящего дневного солнца и/или же использовать его для ритуальных целей. Грот представляет собой искусственно расширенную природную расщелину в пластах девонского песчаника. Кроме того, как отдельные рисунки, встречающиеся по всему Ала-Тею, так и некоторые петроглифы южного святилища могли быть созданы в каменный век, о чём говорит характер ряда изображений.

Наскальные рисунки святилища южный Ала-Тей имеют много общего со скифосибирским звериным стилем, в особенности с тагарской традицией. В этой связи неслучайным может оказаться расположение целой группы кольцевых курганов Ала-Тей 3 и могильника Ала-Тей 4, вплотную примыкающих к западному и юго-западному подножью горы Ала-Тей и датируемых предскифским и скифским временем (Мурзина, 2020, с. 273-275). Курганы группы Ала-Тей 3 расположены в пределах 100 м от святилища. Некоторые курганы предположительно относят- 


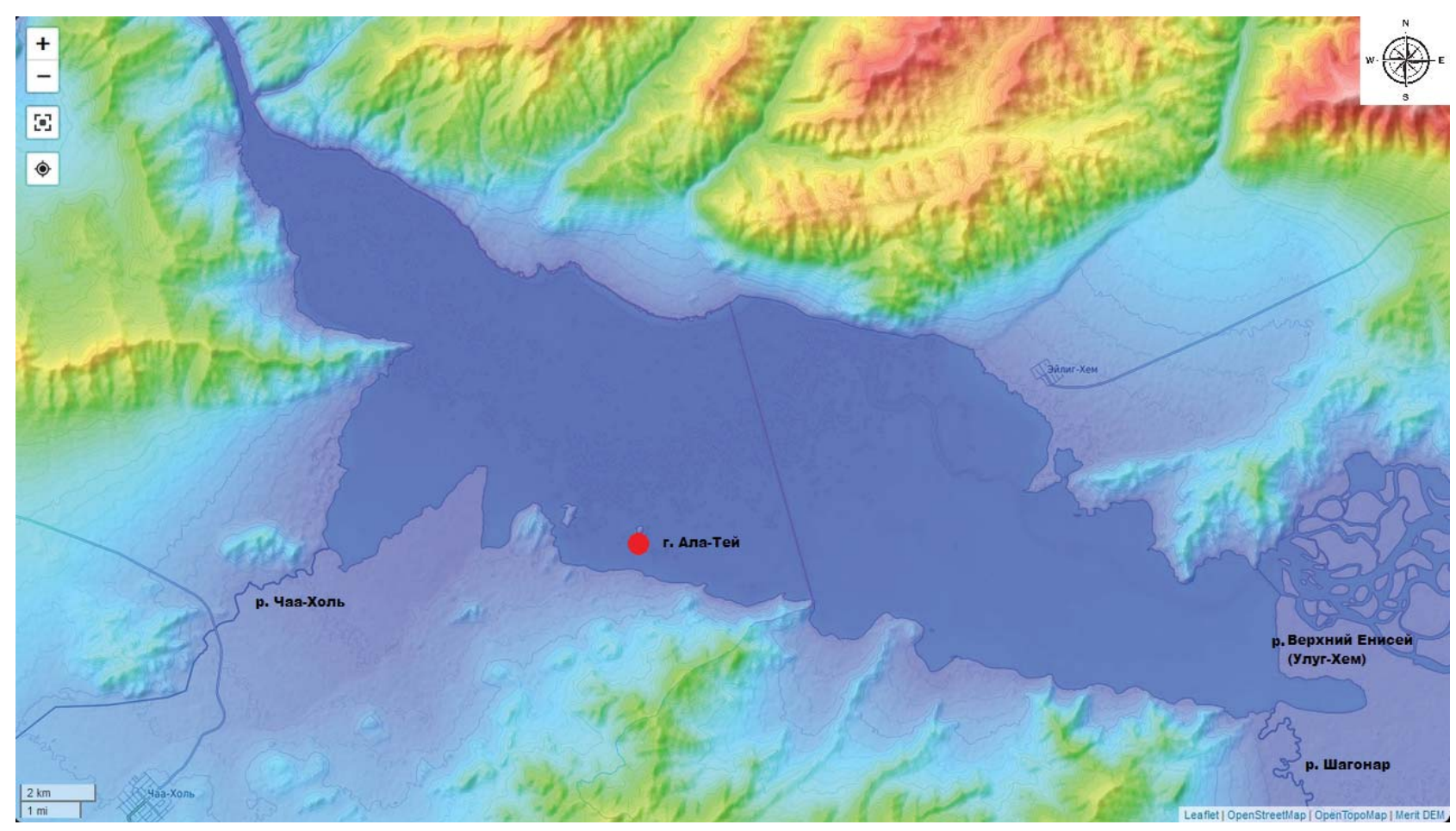

Рис. 12. Топографическая карта зоны затопления реки Енисей в Улуг-Хемской котловине с локализацией горы Ала-Тей.

Fig. 12. The topographic map of the inundation zone of Yenisey river in Ulug-Khem Depression with point of localization of Ala-Tei mountain.

ся к монгун-тайгинской культуре (Мурзина, 2020, с. 273-275), распространённой в XII-IX вв. до нашей эры.

Как уже указывалось, наскальные изображения святилища несут следы сакрального

\section{Примечание:}

1 Любопытно, что в одном из погребений хунну у подножья горы Ала-Тей, была обнаружена гагатовая поясная пластинас петроглифами животных, выполненных в скифском зверином стиле, скомбинированном с традиционным рисунком хунну (Kilunovskaya, Leus, 2018, p. 11, fig.34).

${ }^{2}$ Автор благодарит ИИМК РАН Сакт-Петербурга, и личный состав Тувинской Археологической Экспедиуии. Особую благодарность выражает одному из главных исследователей региона - Вл.А.Семёнову.

${ }^{3}$ Петроглифы этой зоны, выделены светлым тоном по общему контуру очертания, без разграничения на отдельные фигуры, ввиду большой вероятности совершения грубых ошибок.

${ }^{4}$ Материал войдёт в состав следующей статьи по новым обнаружениям наскального искусства Саянской котловины.

5 У подножья горы Ала-Тей, также имеется и могильник эпохи Средневековья - Ала-Тей 2. (Бусова, Килуновская, Леус, Орфинская, 2019, с. 155-158, рис.1,2).

\section{ЛИТЕРАТУРА}

Бусова В.С., Килуновская М.Е., Леус П.М., Орфинская О.В. Шелк в контексте погребального обряда могильника Ала-Тей 2 в Туве // Искусство древнего текстиля. Методы изучения, сохранность, реконструкция. Материалы Российско-Германского семинара (Москва, 11-13 марта 2018) М.: ИА РАН, 2019. C. $155-170$.

Голан А. Миф и символ. М.: Русслит, 1993. 375 с.

Грач А.Д. Петроглифы Тувы. ІІ.(Публикация комплексов, обнаруженных в 1955 г.) // Сб. МАЭ. Т. XVIII. Л.: АН СССР, 1958. С. 339-384.

Длужневская Г.В, Савинов Д.Г Памятники Древности на Дне Тувинского моря. СПб: ИИМК РАН-СПбГУ, 2007. $197 \mathrm{c.}$

Дэвлет Е.Г., Дэвлет М.А. Сокровища наскального искусства Северной и Центральной Азии. М.: ИА РАН, 2011. $382 \mathrm{c.}$ 
Дэвлет М.А. Наскальные изображения Саянского каньона // Археологические открытия 1979 г. / Отв. ред. Б.А. Рыбаков. М.: Наука, 1980. С. 205-206.

Дэвлет М.А. Листы каменной книги Улуг-Хема. Кызыл: Тувинское книжное издательство, 1990. $120 \mathrm{c}$.

Дэвлет М.А., Бадер Н.О., Даркевич В.П., Леонтьев Н.В. Петроглифы Енисея // Археологические открытия 1978 года / Отв. ред. Б.А. Рыбаков. М.: Наука, 1979. С. 223-224.

Есин Ю.Н. К проблеме идентификации тамг киргизов и чиков из «Тан-Хуйяо» // Научное обозрение Саяно-Алтая. 2017. №1 (17). С. 57-75.

Зоткина Л. В. Технологические особенности выполнения выбитых петроглифов // РА. 2014. № 3. C. 89-97.

Килуновская M.Е., Семёнов Вл.А. Оленные камни Тувы // Археологические вести. 1998. №5. С. $143-154$.

Кубарев В. Д. Мифы и ритуалы, запечатлённые в петроглифах Алтая // Археология, этнография и антропология Евразии. 2006. №3 (27). С. 41-54.

Маннай-оол М.Х. Древнее изображение горного козла в Туве// СА. 1967. №1. С. 140-146.

Медведев В.Е. Исследования на Амуре // Археологические открытия 1978 года / Отв. ред. Б.А. Рыбаков. М.: Наука, 1979. С. 251-253.

Миклашевич E.A. Наскальные изображения горы Туран на Среднем Енисее // Результаты изучения материалов археологических исследований. 2018. № 1 (21). С. 24-39.

Kilunovskaya M., Leus P. Recent Excavations of Xiongnu Graves on the Left Bank of the Ulug-Khem in Tuva // The Silk Road. 2018. № 16. P. 1-20.

Новгородова Э.А. Мир петроглифов Монголии. М.: ГРВЛ., 1984. 168 с.

Панкова С.В. Изображения посттагарского и таштыкского времени на скалах Минусинского края // Археологические экспедиции за 2004 год / Ред. Ю. Ю. Пиотровский. СПб: ГЭ, 2005. С. 74-84.

Самамев 3., Базылхан Н., Самамев С. Древнетюркские тамги. Алматы: Абди компани, 2010. 168 с.

Семенов Вл.А. Искусство варварских племен. СПб: ООО «Типография «НП-Принт»», 2015. 400 с.

Badarch N. The coins of Mongol Empire and clan tamgha of Khans (XIII-XIV). Ulaanbaatar: Admon, 2005. $254 \mathrm{p}$.

Мурзина С.P. Новый памятник в зоне затопления Саяно-Шушенской ГЭС - Ала-Тей 4. // Актуальная археология 5. Комплексные исследования в археологии. Материалы Международной научной конференции молодых ученых (13-16 апреля 2020 г., Санкт-Петербург) / Отв. ред. К.В. Конончук. СПб.: Изд-во ООО «Невская Типография», 2020. С. 273-275.

\section{Информация об авторах:}

Бондарь Игорь Александрович, независимый исследователь (г. Кишинёв, Молдавия); igorrr8829@gmail.com

Ленькова Екатерина Николаевна, независимый исследователь (г. Москва, Россия); en.lenkova@physics.msu.ru

\section{REFERENCES}

Busova, V. S., Kilunovskaia, M. E., Leus, P. M., Orfinskaia, O. V. 2019. In Iskusstvo drevnego tekstilia. Metody izucheniia, sokhrannost', rekonstruktsiia (Ancient Textile Art. Study Methods, Preservation, Reconstruction). Moscow: the Institute of Archaeology, Russian Academy of Sciences, 155-170 (in Russian).

Golan, A. 1993. Mif i simvol (Myth and Symbol). Moscow: "Russlit" Publ

Grach, A. D. 1958. In Sbornik Muzeia antropologii i etnografii SSSR (Bulletin of the Peter the Great Museum of Anthropology and Ethnography (Kunstkamera) of the Academy of Sciences of the USSR) 18. Leningrad: Academy of Sciences of the USSR, 339-384 (in Russian).

Dluzhnevskaya, G. V., Savinov, D. G. 2007. Pamiatniki Drevnosti na Dne Tuvinskogo moria (Monuments of Antiquity at the Bottom of the Tuva Sea) Saint Petersburg: Institute for the History of Material Culture, Russian Academy of Sciences, Saint Petersburg State University (in Russian).

Devlet, E. G., Devlet, M. A. 2011. Sokrovishcha naskal'nogo iskusstva Severnoi i Tsentral'noi Azii (Treasures of Rock Art of the North and Central Asia). Moscow: Institute of Archaeology of the RAS (in Russian).

Devlet, M. A. 1980. In Rybakov, B. A. (ed.). Arkheologicheskie otkrytiya 1979 goda (Archaeological Discoveries 1979). Moscow: "Nauka" Publ., 205-206 (in Russian). 
Devlet, M. A. 1990. Listy kamennoi knigi Ulug-Khema (Sheets of the Stone Book of Ulug-Khem). Kyzyl: "Tuvinskoe knizhnoe izdatel'stvo" Publ. (in Russian).

Devlet, M. A., Bader, N. O., darkevich, V. P., Leont'ev, N. V. 1979. In Rybakov, B. A. (ed.). Arkheologicheskie otkrytiia 1978 goda (Archaeological Discoveries of 1978). Moscow: "Nauka" Publ., 223-224 (in Russian).

Esin, Yu. N. 2017. In Nauchnoe obozrenie Saiano-Altaia (Scientific Review of Sayano-Altai) 17 (1). 57-75 (in Russian).

Zotkina, L. V. 2014. In Rossiiskaia Arkheologiia (Russian Archaeology) (3), 89-97 (in Russian).

Kulinskaya, M. E., Semenov, V1. A. 1998. In Arkheologicheskie vesti (Archaeological News) 5. 143-154 (in Russian).

Kubarev, V. D. Yu. 2006. In Arkheologiia, etnografiia i antropologiia Evrazii (Archaeology, Ethnology \& Anthropology of Eurasia) 27 (3), 41-54 (in Russian).

Mannai-ool M. Kh. 1967. In Sovetskaia Arkheologiia (Soviet Archaeology) (3), 140-146. (in Russian).

Medvedev, V. E. 1979. In Rybakov, B. A. (ed.). Arkheologicheskie otkrytiia 1978 goda (Archaeological Discoveries of 1978). Moscow: "Nauka" Publ., 251-253 (in Russian).

Kilunovskaya, M., Leus, P. 2018. In The Silk Road. (16), 1-20 (in English).

Murzina, S. R. 2020 In Konochuk, K. V. (ed.) Aktual'naia arkheologiia: kompleksnye issledovaniia $v$ arkheologii (Current Archaeology: Comprehensive Studies in Archaeology) 5. Saint Petersburg: "Nevskaya Tipografi-ya" Publ., 273-275 (in Russian).

Novgorodova, E. A. 1984. Mir petroglifov Mongolii (The World of Petroglyphs of Mongolia). Moscow (in Russian).

Pankova, S. V. 2005. In Piotrovsky, Yu. Yu. (ed.). Arkheologicheskie ekspeditsii za 2004 god (Archaeological Expeditions in 2004). Saint Petersburg: The State Hermitage, 74-84 (in Russian).

Samashev, Z., Bazylkhan, N., Samashrv, S. 2010. Drevnetiurkskie tamgi (Ancient Turkic Tamgas). Almaty: "Abdi kompani” Publ. (in Russian).

Semenov, V1. A. 2015. Iskusstvo varvarskikh plemen (The Art of Barbaric Tribes). Saint Petersburg: "NP-Print" Publ. (in Russian).

Badarch, N. 2005. The coins of Mongol Empire and clan tamgha of Khans (XIII-XIV). Ulaanbaatar: Admon (in English).

Miklashevich, E. A. 2018. In Rezul'taty izucheniia materialov arkheologicheskikh issledovanii (Theory and Practice of Archaeological Research) 21 (1). 24-39 (in Russian).

\footnotetext{
About the Authors:

Bondar Igor A. Independent researcher, Chisinau, Moldova; igorrr8829@gmail.com

Lenkova Ekaterina N. Independent researcher, Moscow Russian Federationm; en.lenkova@physics.msu.ru

Статья поступила в журнал 01.10.2021 г.

Статья принята к публикации 01.12.2021 г.

Авторы внесли равноценный вклад в работу.
} 